\title{
JENIS DAN KEPADATAN TUNGAU DEBU RUMAH DI KELURAHAN MALALAYANG 1 KECAMATAN MALALAYANG KOTA MANADO
}

\author{
${ }^{1}$ Stefany P. Kristin \\ ${ }^{2}$ Josef S. B.Tuda \\ ${ }^{2}$ Greta J. P. Wahongan
}

\author{
${ }^{1}$ Kandidat Skripsi Fakultas Kedokteran Univesitas Sam Ratulangi Manado \\ ${ }^{2}$ Bagian Parasitologi Fakultas Kedokteran Universitas Sam Ratulangi Manado \\ Email :patriciafany@yahoo.com
}

\begin{abstract}
House dust mites are distributed all over the world, including Indonesia. Inside the house, house dust mites can be found on the pillow, home furniture, carpets, clothing, etc. House dust mites can also be found outside such as in bird nests, mammal skin surfaces and other animals. House dust mites population depends on many factors inter alia temperature and humidity. This study aimed to determine the species and density of house dust mites in Malalayang 1, Manado. This was a descriptive survey study with a cross sectional design. The results showed that the species of house dust mites in Malalayang 1 were Dermatophagoides spp., Glycyphagus destructor, Acarus spp, Cheyletus spp, and Tarsonemus spp. House dust mites were more common in the living rooms than the bedrooms. House dust mite average density in the bedrooms was 1.9 and in the living rooms 1.8. Conclusion: In Malalayang 1 Manado, there were 5 types of house dust mites: Dermatophagoides spp., Glycyphagus destructor, Acarus spp, Cheyletus spp, and Tarsonemus spp. The most commonly found species was Dermatophagoides spp. House dust mite density was higher in the bedrooms than in the living rooms.
\end{abstract}

Keywords: density, species, house dust mites

\begin{abstract}
Abstrak: Tungau Debu Rumah (TDR) tersebar di seluruh dunia termasuk di Indonesia. Di dalam rumah TDR ditemukan di bantal, perabotan rumah tangga, celah karpet, pakaian, dll. Di luar rumah, TDR juga dapat ditemukan misalnya pada sarang burung, permukaan kulit mamalia dan binatang lainnya. Banyaknya populasi TDR tergantung pada faktor suhu dan kelembaban udara. Penelitian ini bertujuan untuk mengetahui jenis dan kepadatan TDR yang ditemukan di kelurahan Malalayang 1 Kecamatan Malalayang Kota Manado. Penelitian ini menggunakan metode surve deskriptif dengan pendekatan potong lintang. Hasil penelitian menunjukkan bahwa jenis TDR di Kelurahan Malalayang 1 yaitu Dermatophagoides spp. Glycyphagus destructor, Acarus spp, Cheyletus spp, dan Tarsonemus spp. Di ruang keluarga lebih banyak ditemukan TDR dibandingkan dengan ruang tidur. Kepadatan rata-rata TDR pada ruang tidur 1,9 sedangkan di ruang keluarga 1,8. Simpulan: Di Kelurahan Malalayang 1 ditemukan TDR jenis Dermatophagoides spp. Glycyphagus destructor, Acarus spp, Cheyletus spp, dan Tarsonemus spp, yang terbanyak ialah jenis Dermatophagiodes spp. Kepadatan TDR lebih tinggi di ruang tidur dibandingkan dengan ruang keluarga.
\end{abstract}

Kata kunci: kepadatan, jenis, tungau debu rumah.

Sejak zaman dahulu tungau debu rumah telah menghuni dunia ini termasuk di Indonesia. Antonie van Leeuwenhoek, menyatakan bahwa terdapat tungau yang hidup pada debu. Kini penelitian-penelitian menunjukkan bahwa tungau domestik dapat ditemukan pada debu rumah di seluruh dunia. ${ }^{1}$ Tungau ini biasanya 
ditemukan di dalam rumah yaitu di bantal, perabotan rumah tangga, celah karpet, permadani, dinding kayu atau bambu, tikar, serta lantai di bawah karpet. ${ }^{2}$ Tungau debu rumah (TDR) dapat juga ditemukan diluar rumah, misalnya pada sarang burung, permukaan kulit mamalia dan binatang lainnya. $^{3}$

TDR merupakan salah satu masalah serius bagi kehidupan manusia. Karena tungau debu merupakan alergen hirup sebagai faktor pencetus timbulnya penyakit alergi seperti dermatitis atopik, asma bronkial dan rinitis. Bagian TDR yang mengandung alergen ialah kutikula, organ seks dan saluran cerna. Selain bagian badan, feses TDR juga mempunyai sifat antigenik. ${ }^{3}$ Pada karpet seluas $1 \mathrm{~m}^{2}$ dapat berisi sebanyak \pm 100.000 tungau debu. ${ }^{4}$ Makanan TDR ialah serpihan kulit (skuama) manusia atau binatang.

Walaupun TDR berukuran mikroskopik tetapi TDR ini sangat berdampak buruk bagi kesehatan manusia. Penelitian epidemiologis Dowse et al. menunjukkan TDR berperan sangat penting pada kenaikan prevalensi asma di South Fore Papua New Guinea. ${ }^{4}$

Populasi tungau debu di dalam rumah bergantung pada beberapa faktor: 1) tinggi rendahnya rumah dari permukaan laut; 2) daerah dengan musim panas yang lebih panjang dari musim hujan; 3) adanya berbagai binatang di dalam rumah; 4) rumah yang kotor dan banyak debu; 5) suhu kelembaban optimum optimal bagi pekembangan populasi tungau debu rumah ialah $25^{\circ}-30^{\circ} \mathrm{C}$ dan kelembaban relatif 70 80\% dengan kelembaban kritis 60-65\%. Perkembangbiakan tungau debu rumah terganggu pada suhu di atas $32^{\circ} \mathrm{C} .{ }^{3}$

Indonesia merupakan negara kepulauan yang dikelilingi laut. Hal ini menyebabkan Indonesia termasuk dalam negara tropis yang merupakan tempat berkembang biak bagi TDR, termasuk Manado dengan mayoritas 0-240 m ketinggian dari permukaan laut dengan kisaran 95\%. Suhu udara rata-rata di Manado tahun 2010 berkisar antara 25,8$27,0^{\circ} \mathrm{C}$. Tempat-tempat yang letaknya berdekatan dengan pantai mempunyai suhu rata-rata relatif tinggi dengan kelembaban udara rata-rata bervariasi antara $80 \%$ sampai $87 \%{ }^{5}$

Prevalensi penyakit asma di Indonesia, meningkat dari 4,2\% pada tahun 1995 menjadi 5,4\% pada tahun 2003., Berdasarkan Riskesdas 2007 prevalensi asma di Sulawesi Utara mencapai 2,7\% penderita dari seluruh penduduk ${ }^{6}$ sehingga dapat dikatakan Kota Manado merupakan salah satu tempat yang baik untuk perkembangbiakan TDR. Oleh karena itu maka penulis tertarik untuk melakukan penelitian terhadap tungau debu rumah yang terdapat di wilayah kota Manado, khususnya di kecamatan Malalayang.

\section{METODE PENELITIAN}

Penelitian ini menggunakan metode survei deskriptif dengan pendekatan potong lintang. Identifikasi tungau serta pengolahan data dilakukan di Laboratorium Parasitologi Fakultas Kedokteran Universitas Sam Ratulangi Manado.

Penelitian ini dilaksanakan pada bulan November-Desember 2012. Populasi terjangkau ialah debu dari rumah yang ada di Kelurahan Malalayang 1, Kecamatan Malalayang Kota Manado. Sampel penelitian berupa debu yang dikumpulkan dari kasur dan lantai serta sofa pada rumah penduduk menggunakan metode simple random sampling. Jumlah sampel rumah yang akan diperiksa dihitung berdasarkan rumus besar sampel minimum atau yang sering disebut rumus Snedecor Cochran.

$$
n_{1}=\frac{4 \times p \times q}{L 2}
$$

ket: $\mathrm{n}_{1}=$ Besar sampel pada tahap pertama

$\mathrm{p}=$ Persentase taksiran hal yang diteliti

$\mathrm{q}=100-\mathrm{p}$

$\mathrm{L}=$ Galat/tingkat eror

$$
n_{1}=\frac{4 \times 95 \times 5}{25}=76
$$

Terhadap nilai $\mathrm{n}_{1}$ harus dilakukan koreksi dengan jumlah populasi referensi 
yaitu dengan rumus:

$$
n_{2}=\frac{n_{1}}{1+\frac{n_{1}}{N}}
$$

Ket: $\mathrm{N}=$ Jumlah populasi referens

Untuk menghindari drop out maka $n_{2}$ dapat ditambah. Penambahan ini memadai dengan jumlah sebesar $10 \%$ dari $n_{2}$ dapat diperoleh dengan cara:

$n_{3=n^{2}}+0,10 \times n_{2}=73,1+0,10 \times 73,1=$ 80,41 dibulatkan menjadi 80 . Jadi jumlah rumah yang akan diperiksa ialah 80 rumah.

\section{Pengambilan debu}

Debu dikumpulkan dengan penyedot debu (Vaccum cleaner) maximus 400 watt selama 2 menit di daerah seluas $1 \mathrm{~m}^{2}$. Debu diangkat dengan kertas lalu dimasukkan ke dalam cawan Petri, kemudian cawan di tutup. Sampel debu yang telah dikumpul diperiksa di Laboratorium Parasitologi Fakultas Kedokteran Unsrat.

IdentifikasiTungau Debu (secara langsung)

Sejumlah $0,1 \mathrm{~g}$ debu rumah dimasukkan kedalam cawan petri kemudian dilihat dibawah mikroskop stereo. Hitung jumlah tungau debu yang terlihat. Spesies tungau debu diidentifikasi menggunakan kunci identifikasi Heru Sundaru dan Mj Collof et al. ${ }^{1}$ Untuk identifikasi spesies lebih lanjut, tungau debu dibuat preparat. Jenis TDR ialah spesies TDR yang ditemukan dari hasil pengamatan mikroskopik sesuai dengan kunci identifikasi.

\section{HASIL PENELITIAN}

Terdapat 5 spesies tungau debu rumah yang ditemukan dalam penelitian.

Dermatophagoides spp. mempunyai ciri-ciri kaki lebih besar dibandingkan dengan tungau lain, terdapat setae (rambut) pada tubuh dengan panjang bervariasi.
Pada tungau jantan terdapat aedeagus dan sepasang kaki genital skleritin.

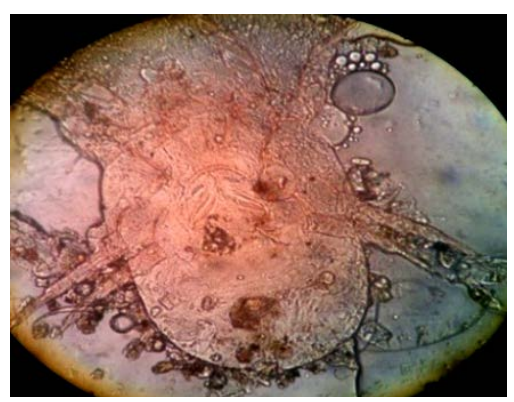

Glycyphagus destructor mempunyai banyak setae (rambut) pada tubuhnya dan ujung-ujung kaki (tarsus) memanjang

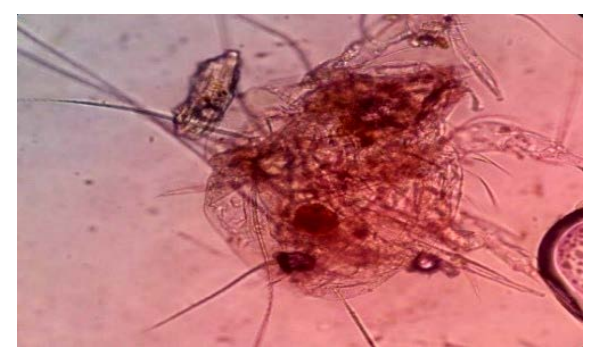

Acarus spp berbentuk gemuk dan membulat dan pada bagian dorsal terdapat lekuk transversal.

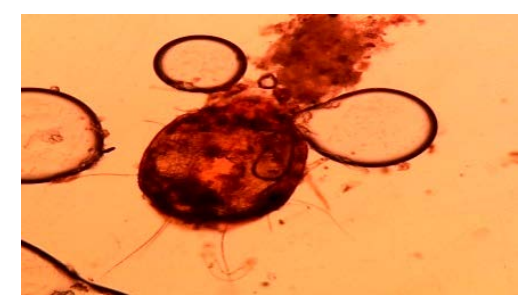

Cheyletus spp. berukuran besar (500$900 \mu \mathrm{m}$ ), mempunyai palpi (bagian dari mulut) yang besar. Pada tiap palpi tersebut terdapat cakar tunggal.

Tarsonemus spp. berukuran kecil (150$300 \mu \mathrm{m})$ dan permukaan dorsal terdiri dari beberapa lapisan yang saling tumpang tindih. 
Tabel 1. Kamar tidur yang positif tungau debu

\begin{tabular}{clcc} 
No & \multicolumn{1}{c}{ Jenis Tungau } & $\begin{array}{c}\text { Jumlah yang positif } \\
\text { tungau }(\mathrm{n}=80)\end{array}$ & $\%$ \\
\hline 1 & Dermatophagoides spp & 17 & 21,25 \\
2 & Glycyphagus destructor & 6 & 7,5 \\
3 & Acarus spp & 13 & 16,25 \\
4 & Cheyletus spp & 5 & 6,25 \\
5 & Tarsonemus spp & 8 & 10
\end{tabular}

Tabel 2. Ruang keluarga yang positif tungau debu

\begin{tabular}{clcc}
\hline No & \multicolumn{1}{c}{ Jenis Tungau } & $\begin{array}{c}\text { Jumlah yang positif } \\
\text { tungau }(\mathrm{n}=80)\end{array}$ & $\%$ \\
& Dermatophagoides spp & 20 & 25 \\
2 & Glycyphagus destructor & 8 & 10 \\
3 & Acarus spp & 10 & 12,5 \\
4 & Cheyletus spp & 6 & 7,5 \\
5 & Tarsonemus spp & 4 & 5 \\
\hline
\end{tabular}

Tabel 3. Jumlah tungau debu yang berhasil diisolasi dari kamar tidur

\begin{tabular}{|cccc|}
\hline No & Jenis Tungau & $\begin{array}{c}\text { Jumlah tungau yang berhasil } \\
\text { diisolasi }\end{array}$ & $\%$ \\
\hline 1 & Dermatophagoides spp & 31 & 36,9 \\
\hline 2 & Glycyphagus destructor & 9 & 10,7 \\
\hline 3 & Acarus spp & 22 & 26,1 \\
\hline 4 & Cheyletus spp & 8 & 9,5 \\
\hline 5 & Tarsonemus spp & 14 & 16,6 \\
\hline & Total & 84 & 100 \\
\hline
\end{tabular}

Tabel 4. Jumlah tungau debu yang berhasil diisolasi dari ruang keluarga

\begin{tabular}{|cccc|}
\hline NO & Jenis Tungau & $\begin{array}{c}\text { Jumlah tungau yang } \\
\text { berhasil diisolasi }\end{array}$ & $\%$ \\
\hline 1 & Dermatophagoides spp & 37 & 47.4 \\
\hline 2 & Glycyphagus destructor & 8 & 10.2 \\
\hline 3 & Acarus spp & 14 & 17.9 \\
\hline 4 & Cheyletus spp & 13 & 16.6 \\
\hline 5 & Tarsonemus spp & 6 & 7.6 \\
\hline & Total & 78 & 100 \\
\hline
\end{tabular}

Tabel 5. Kepadatan tungau debu rumah (TDR)

\begin{tabular}{|cc|}
\hline Kepadatan TDR pada kamar tidur & 1,9 \\
\hline Kepadatan TDR pada ruang keluarga & 1,8 \\
\hline
\end{tabular}

\section{BAHASAN}

Dari hasil penelitian ternyata di seluruh kamar tidur yang telah diperiksa dan positif TDR yang tersering ditemukan ialah Dermatophagoides spp., diikuti oleh
Acarus spp. menempati posisi ke-2 tertinggi di kamar tidur, selanjutnya Tarsonemus spp., Glycyphagus destructor dan yang paling sedikit ialah Cheyletus spp. 
Dermatophagoides spp. menempati urutan tertinggi dibandingkan spesies lainnya, kemudian ke-2 ialah Acarus spp., Glycyphagus destructor, Cheyletus spp., dan yang paling sedikit yaitu Tarsonemus spp. Berdasarkan hal tersebut dapat dikatakan bahwa Dermatophagoides spp merupakan TDR yang tersering ditemukan di Kelurahan Malalayang 1. Hasil penelitian ini serupa dengan hasil penelitian Ichan (2002) di Kelurahan Sario Tumpaan Kota Manado yang mendapatkan Dermatophagoides spp. menempati persentasi tertinggi (82\%) TDR. Perbedaan suhu dan kelembaban mungkin menjadi salah satu faktor yang menyebabkan hasil penelitian ini berbeda dengan penelitian sebelumnya.

Dari hasil penelitian ini ternyata ruang keluarga lebih banyak yang positif TDR dibandingkan dengan kamar tidur. Begitu pula dengan TDR yang berhasil diisolasi lebih banyak di ruang keluarga. Hal ini disebabkan karena di ruang keluarga lebih banyak aktivitas yang berlangsung tiap harinya dibandingkan dengan kamar tidur. Jumlah tungau debu yang berhasil diisolasi, lebih banyak di ruang keluarga dari pada di kamar tidur.

Kelembaban udara merupakan salah satu faktor pertumbuhan TDR. Khususnya daerah Manado, bulan NovemberDesember memiliki curah hujan tinggi sehingga kelembaban udara meningkat.

\section{SIMPULAN}

Berdasarkan hasil penelitian yang dilakukan dapat disimpulkan bahwa TDR yang ditemukan di Kelurahan Malalayang 1 ialah jenis Dermatophagoides spp. Glycyphagus destructor, Acarus spp, Cheyletus spp, dan Tarsonemus spp, dan yang terbanyak ialah jenis Dermatophagiodes spp. Kepadatan TDR lebih tinggi di ruang tidur dibandingkan dengan ruang keluarga.

\section{DAFTAR PUSTAKA}

1. Natadisara D, Agoes R. Parasitologi kedokteran ditinjau dari organ tubuh yang diserang. Jakarta: ECG, 2009; p.345-6, 400-1.

2. Dust Mites. 2012 Available from: URL:http://www.dustmite.net/locating-dust-mites/ diakses 3 oktober 2012.

3. Sungkar S. Artropoda penyebab alergi dan reaksi toksin. Sutanto I, Ismid IS, Sjarifudin PD, Sungkar S, editors. Buku ajar parasitologi kedokteran (4 ed.). Jakarta: Balai penerbit FKUI, 2009; p.289-91.

4. Kontrol asma dengan control lingkungan rumah. 2012 Available from: URL:http://dinkes.jogjaprov.go.id/ber ita/detil_berita/477-stop-asma-anakdengan-kontrol-lingkungan-rumah

5. Seksi neraca wilayah dan analisis statistik. Statistik daerah kota Manado, 2011.

6. Crowther D, Horwood J, Baker N. House dust mites and the built environment. A literature review, 2000. 